Fianolita Purnaningtias, dkk.

\title{
ANALISIS PERAN PENDIDIKAN MORAL UNTUK MENGURANGI AKSI BULLY DI SEKOLAH DASAR
}

\author{
Fianolita Purnaningtias, Nuril Aika, Lisanatul Fasihah, Moh. Salman Al farisi, \\ Ahmad Sucipto, Zherin Mei Biana Putri \\ STKIP PGRI Sumenep \\ fianolitapurnaningtias@gmail.com, nurilaika1405@gmail.com, lisanatulfasihah19@gmail.com, \\ salmanfares14@gmail.com, ahmadsuciptocipto55@gmail.com, mybimadura76846@gmail.com
}

\begin{abstract}
Abstrak
Tulisan ini mendeskripsikan tentang analisis peran pendidikan moral untuk mengurangi aksi bully di sekolah dasar. Pengembangan pendidikan moral siswa sangat penting dilakukan untuk meningkatkan moral siswa sebagai jati diri dan karakter bangsa. penerapan pendidikan moral siswa di sekolah dasar merupakan salah satu alternatif mendasar serta mendalam untuk mengurangi kegiatan penyimpangan sosial seperti bully. Tindakan bully sangat berbahaya bagi karakter anak. Selain dengan intelektual yang tinggi sebagai generasi penerus bangsa maka sudah sepantasnya untuk memiliki moralitas yang baik untuk menunjang terbentuknya negara dengan bangsa yang beradab dan berbudi pekerti. Tentunya hal ini tidak terlepas dari peran pendidikan dan pendidik. Bentuk aksi penyimpangan berupa bully ini perlu perhatikan khusus, khususnya di sekolah dasar, oleh karena itu guru-guru harus mampu meningkatkan pendidikan moral siswa sehingga hal penyimpangan seperti bully tidak akan terjadi dan cita cita bangsa dapat tercapai.
\end{abstract}

Kata kunci: pendidikan moral, bully, guru

\begin{abstract}
This paper describes the analysis of the role of moral education to reduce bullying in elementary schools. The development of student moral education is very important to do to improve student morale as national identity and character. The application of moral education to students in primary schools is one of the fundamental and deep alternatives to reduce social deviations such as bullying. Bullying is very dangerous for a child's character. Besides having high intellectuals as the next generation of the nation, it is appropriate to have good morality to support the formation of a nation with a civilized and virtuous nation. Of course this is inseparable from the role of education and educators. The form of deviations in the form of bullying needs special attention, especially in primary schools, therefore teachers must be able to improve the moral education of students so that deviations such as bullying will not occur and the nation's goals can be achieved
\end{abstract}

Keywords: moral education, bully, teacher

\section{Pendahuluan}

Pada hakikatnya pendidikan merupakan hal yang sangat di butuhkan dalam kehidupan manusia, dimana dengan pendidikanlah kehidupan manusia dapat berkembang ke arah yang lebih modern dan kreatif. Pendidikan bisa berlangsung dimana saja, tidak hanya dalam instansi formal, tetapi bisa dimana saja. Pendidikan bertujuan membantu manusia menjadi cerdas dan mendorong manusia untuk menjadi lebih baik. Artinya manusia cerdas lebih mudah daripada manusia menjadi lebih baik. Dengan demikian dapat dikatakan bahwa masalah moral merupakan persoalan mendasar yang mengisi kehidupan manusia kapanpun dan dimanapun (Yuyarti. 2018:169).

Menurut Agus Zaenul dalam Ilham Hudi (2017:31) ada banyak faktor yang berkontribusi mempengaruhi kualitas moral di kalangan siswa. Salah satu faktor tersebut; adalah keteladanan dari guru, orangtua, dan masyarakat.yang kedua disebabkan oleh krisis keteladanan di kalangan pemimpin bangsa yang menjadikan anak tidak lagi peduli dengan nasihat guru dan benyak hal lain. 
Di kalangan generasi muda hari ini banyak sekali penyimpangan yang terjadi akibat kurangnya pendidikan moral dan mirisnya berbagai penyimpangan tersebut di anggap biasa dan bukan merupakan hal yang serius, padahal jika penyimpangan tersebut sudah dilakukan sejak usia muda maka akan menjadi kebiasaan hingga dewasa dan bisa menjadi karakter yanga kan sangat sulit untuk dirubah. Contoh penyimpangan yang sering kita jumpai adalah tindakan bullying, tindakan penyimpangan ini merupakan akibat dari rapuhnya karakter dalam pendidikan moral serta kondisi lingkungan yang memungkinkan tindakan Ibullying ini terjadi.

Menurut Craigh and Pepler (1998) dalam Afien Murtie (2014:19) Bullying dikatakan sebagai suatu tindakan negative baik secara verbal maupun fisik yang dilakukan oleh pelaku kepada korbannya dengan menunjukkan sikap permusuhan. Tindakan ini menimbulkan distress bagi korbannya karena dilakukan berulang kali dalam kurun waktu tertentu. Ironisnya di dalam bullying ada perbedaan kekuatan antara pelaku yang lebih kuat dengan korban yang lebih lemah baik secara fisik maupun mental.

Guna mengurangi tindakan penyimpangan tersebut adalah salah satunya dengan memperhatikan karakter seorang anak melalui pendidikan moral khususnya di lingkungan sekolah dasar. Disinilah peran pendidikan moral sangat diperlukan untuk menerapkan nilai nilai moral agar peserta didik tidak melakukan segala bentuk penyimpangan salah satunya adalah bullying.

\section{Pembahasan}

1. Hakikat Pendidikan Moral

a) Pengertian pendidikan Moral

Kata moral berasal dari bahasa latin "mores" kata jama' dari "mos" yang berarti adat kebiasaan. Dalam bahasa Indonesia, moral diterjemahkan dengan arti tata susila. Di sini, moral berarti perbuatan baik dan buruk yang didasarkan kepada masyarakat. Dengan kata lain, moral merupakan perbuatan baik dan buruk yang sesuai dengan ide-ide umum, wajar, dan diterima meliputi kesatuan sosial atau lingkungan tertentu. (Hamzah ya'qub dalam Amirullah syarbini 2016:27). Moral selalu mengacu pada baik buruk manusia, sehingga moral adalah bidang kehidupan manusia dilihat dari kebaikan manusia. Norma moral dipakai sebagai tolak ukur segi kebaikan manusia.

Sedangkan pendidikan moral sendiri berasal dari kata paedagogi, dalam bahasa Yunani pae artinya anak dan ego artinya aku membimbing. Secara harafiah pendidikan berarti aku membimbing anak, sedang tugas pembimbing adalah membimbing anak agar menjadi dewasa. Secara singkat Driyarkara yang dikutip oleh Istiqomah mengatakan bahwa pendidikan adalah suatu usaha secara sadar yang dilakukan oleh pendidik melalui bimbingan atau pengajaran dan latihan untuk membantu peserta didik mengalami proses pemanusiaan diri ke arah tercapainya pribadi dewasa, susila dan dinamis Istiqomah dalam Sigit Dwi Kusrahmadi (2007: 123).

Menurut $\mathrm{H}$. Kirschenbaum dalam Fatimah Ibda (2012:340) Pendidikan moral dikatakan berhasil bila peserta didik mampu menghasilkan nilai-nilai dan tingkah laku moral yang ditransmisikan, baik secara verbal maupun perilaku. Pendidikan moral bertujuan menghasilkan individu yang mengerti nilai-nilai moral dan konsisten dalam melaksanakannya sesuai dengan konsep moral yang diajarkan agama, tradisi moral masyarakat, dan kebudayaan. Pendidikan moral itu sendiri terdiri dari sejumlah komponen yang berkaitan dengan ilmu pengetahuan tentang tradisi moral, penalaran moral, rasa kasih dan altruisme, serta tendensi moral

Berdasarkan penjelasan diatas maka dapat disimpulkan bahwa Pendidikan moral adalah suatu proses, pendekatan yang seharusnya digunakan secara komperhensip, pendidikan moral ini sebaiknyanya dilakukan secara kondusif baik di lingkungan sekolah, rumah dan masyarakat, dan sudah menjadi kewajiban 
Fianolita Purnaningtias, dkk.

untuk semua pihak agar ikut serta dalam meningkatkan pendidikan moral anak agar tercipta generasi penerus bangsa yang berakhlak dan bermoral.

b) Perkembangan pendidikan moral

Dapat dipahami bahwa moral merupakan pandangan manusia tentang baik dan buruk, dimana yang menjadi ukuran baik dan buruk tersebut adalah kesepakatan manusia atau masyarakat yang menempati suatu wilayah tertentu. Perkembangan moral seorang anak banyak dipengaruhi oleh lingkungannya. Anak memperoleh nilai-nilai moral dari lingkungannya, terutama dari orangtuanya. Peranan orangtua sangatlah penting, terutama pada waktu anak masih kecil.

Menurut syamsu yusuf dalam Amirullah syarbini (2016:58) Proses perkembangan moral anak dapat berlangsung melalui beberapa cara, sebagai berikut:

1) Pendidikan langsung, yaitu melalui penanaman pengertian tentang tingkah laku yang benar dan salah, atau baik dan buruk oleh orangtua, guru, atau orang yang lebih dewasa di lingkungannya. Orang yang lebih dewasa di lingkungan anak harus memberikan teladan yang baik.

2) Identifikasi, yaitu dengan cara mengidentifikasi atau meniru penampilan atau tingkah laku moral seseorang yang menjadi idolanya, seperti orangtua, guru, kyai, artis, atau orang yang lebih dewasa di lingkungannya.

3) Proses coba-cobaa, yaitu dengan cara mengembangkan tingkah laku moral secara coba-coba. Tingkah laku baik yang mendapat pujian atau penghargaan akan terus dikembangkan, sementara tingkah laku buruk yang mendatangkan hukuman atau celaan akan dihentikan.

Beberapa cara diatas merupakan penjabaran proses perkembangan moral anak yang dapat diterapkan dalam tahap mengembangkan moral anak. Menurut Amirullah Syarbini (2012:59-61) Berdasarkan hasil penelitian Lawrence Kohlberg selama 18 tahun, perkembangan moral anak dibagi ke dalam tiga tingkat (level) dan enam tahap (stage), di mana tiap-tiap tingkat terdiri dari dua tahap. Secara ringkas perkembangan moral versi Kohlberg tersebut dapat dideskripsikan sebagai berikut.

1) Pra-konversional (4-9 tahun). Pada tingkat ini, anak mengenal baik-buruk, benar-salah suatu perbuatan, dari sudut konsekuensi (dampak/akibat) menyenangkan (ganjaran) atau menyakiti (hukuman) secara fisik, atau enak tidaknya perbuatan yang diterima. Tingkat ini terdiri dari dua tahap, yaitu tahap orientasi hukuman dan kepatuhan, dan tahap relativis instrumental. Pada tahap orientasi hukuman dan kepatuhan, anak menilai baik-buruk, atau benar-salah dari sudut dampak (hukuman dan ganjaran) yang diterimanya dari yang mempunyai otoritas (yang membuat aturan). Baik orangtua atau orang dewasa lainnya. Di sini anak mematuhi aturan orangtua agar menghindari hukuman. Sedangkan pada tahap orientasi relativis instrumental, perbuatan baik/benar adalah yang berfungsi sebagai instrumen (alat) untuk memenuhi kebutuhan kepuasan diri. Dalam hal ini, hubungan dengan orang lain dipandang sebagai hubungan orang di pasar (hubungan jual beli). Dalam melakukan atau memberikan sesuatu kepada orang lain, bukan karena rasa terima kasih atau sebagai curahan kasih sayang, tetapi bersifat pamrih (keinginan untuk mendapatkan balasan).

2) Konvensional (10-15 tahun). Pada tingkat ini, anak memandang perbuatan baik/benar, atau berharga bagi dirinya apabila dapat memenuhi persetujuan orang lain, berkembang sikap konformitis, loyalitas, atau penyesuaian diri terhadap keinginan kelompok, atau aturan sosial masyarakat. Tingkat konvensional ini dibagi dalam dua tahap, yaitu orientasi kesepakatan antarpribadi atau orientasi anak baik dan tahap orientasi hukum dan ketertiban. Pada tahap orientasi kesepakatan antarpribadi, anak memandang suatu perbuatan itu baik atau berharga bagi dirinya apabila dapat menyenangkan, membantu, atau disetujui/ 
diterima orang lain. Sedangkan pada tahap orientasi hukum dan ketertiban, perilaku yang baik adalah melaksanakan atau menunaikan tugas/kewajiban sendiri, menghormati otoritas, dan memelihara ketertiban sosial.

3) Pasca-konvensional (16 tahun sampai dewasa). Pada tingkat ini ada usaha individu untuk mengartikan nilai-nilai atau prinsip-prinsip moral yang dapat diterapkan atau dilaksanakan terlepas dari otoritas kelompok, pendukung, atau orang yang memegang/menganut prinsip-prinsip moral tersebut. Juga terlepas apakah individu yang bersangkutan kelompok itu atau bukan. Tingkat ini terdiri dari dua tahap, yaitu tahap orientasi kontrol sosial legalistis dan tahap orientasi prinsip etika universal. Pada tahap orientasi control sosial legalistis, perbuatan baik cenderung dirumuskan dalam kerangka hak-hak individual yang umum, dan dari segi aturan atau patokan yang telah diuji secara kritis serta disepakati oleh seluruh masyarakat. Dengan demikian, perbuatan yang baik itu adalah yang sesuai dengan perundangundangan yang berlaku. Sedangkan pada tahap orientasi prinsip etika universal, kebenaran ditentukan oleh keputusan kata hati, sesuai dengan prinsip-prinsip etika yang logis, universalitas, dan konsistensi. Prinsip-prinsip etika universalitas ini bersifat abstrak, seperti keadilan, kesamaan hak asasi manusia, dan penghormatan kepada martabat manusia.

2. Hakikat Bullying

a. Pengertian Membully

Bullying yang berasal dari bahasa Inggris "bully" yang berarti menggertak atau mengganggu, bullying dapat diartikan dengan sebuah situasi dimana terjadi penyalahgunaan kekuasaan atau kekuatan. Kekuatan di sini tidak hanya secara fisik, tapi juga mental. Akhir akhir ini mem-bully menjadi persoalan yang banyak di temui di kalangan pelajar, lebih lebih pada siswa sekolah dasar yang belum memahami secara sempurna arti dari kesatuan bangsa, dan kurangnya perhatian dan pengawasan dari berbagai pihak.
Menurut Herbert Lee dalam (Sisca,Indriyani 2019:11) mendefinisikan bullying sebagai suatu hal yang mengerikan dan kejam yang dilakukan oleh seseorang kepada anak atau sekelompok anak. Bullying dapat terjadi sekali atau berulang ulang. Korban bullying akan merasakan malu, sakit atau terhina dan terancam. Adapun pelaku bullying mungkin saja tidak menyadarinya. Dapat disimpulkan bahwa menurut Herber perilaku bullying dilakukan oleh pelaku bullying secara berulang ulang, dan berdampak pada psikologis korban perilaku bullying.

Dikatakan sebagai bullying karena sifat perilaku ini mengganggu korban sehingga membuat mereka merasa tidak nyaman sampai pada keadaan putus asa apabila tidak bisa mengatasi dan merasa tidak ada pula yang membantu mereka untuk mengatasinya. Bullying merupakan tindakan yang bersifat mengganggu dan bahkan mencelakai secara fisik, mental, maupun sosial seseorang yang dilakukan oleh pelaku terhadap korban mereka. Perilaku mengganggu atau bullying ini biasanya dilakukan dalam jangka waktu yang lama, berbulan-bulan bahkan sampai beberapa tahun ketika si pelaku masih bisa bertemu dengan korbanya. Sifatnya yang terus-menerus dan cenderung menetap ketika tak segera mendapat penanganan dengan baik inilah yang membuat korban bullying sangat dirugikan terutama secara psikis/mental.

Berdasarkan definisi-definisi tentang bullying di atas, maka dapat disimpulkan bahwa bullying merupakan keinginan untuk melukai baik fisik maupun mental yang dilakukan oleh seseorang atau sekelompok orang kepada orang lain secara berulangulang, yang terjadi karena adanya ketidak seimbangan kekuatan antara pelaku dan korban serta menimbulkan kepuasan dari pelaku dalam melakukan aksi bullying, yang mana tindakan ini akan sangat berpengaruh terhadap moral serta kepribadian seseorang.

Seseorang yang sudah pernah melakukan bully maka ia akan 
Fianolita Purnaningtias, dkk.

menganggap aksi itu biasa biasa saja dan akan melakukannya kembali dilain waktu, hal ini di pengaruhi oleh kepuasan diri yang di rasakan saat mem-bully yang berakibat tehadap degradasi moral seseorang.

b. Bentuk bentuk Membully

Ada empat jenis macam bullying, diantaranya:

\section{1) Bullying Verbal}

Bullying verbal adalah berupa julukan nama, celaan, fitnah, kritikan kejam, penghinaan, pernyataan-pernyataan yang bernuansa ajakan seksual atau pelecehan, seksual, teror, surat-surat yang mengintimidasi, tuduhan-tuduhan yang tidak benar, kasak-kusuk yang keji dan keliru, gosip dan sebagainya.

Bullying verbal merupakan salah satu jenis yang paling sederhana dan mudah dilakukan, dan bully bentuk verbal akan menjadi awal dari perilaku bully yang lainnya, serta dapat menjadi langkah awal menuju pada kekerasan yang lebih lanjut.

\section{2) Bullying Fisik}

Bullying fisik termasuk dalam katagori kekerasan langsung yang mengacu pada tindakan yang menyerang fisik atau psikologis seseorang secara lansung, yang termasuk dalam katagori ini seperti penculikan, penyiksaan, dan penganiayaan, semua tindakan tersebut merupakan tindakan yang tidak benar yang mengganggu hak-hak asasi manusia yang paling mendasar, yakni hak untuk hidup (Jamil Salmi dalam Eli Wardiati 2017:15).

Jadi Bullying fisik adalah aksi bully yang dapat dilihat dengan mata dan di rasakan, seperti halnya memukuli, menggigit, meludahi, menampar, mencekik, dan merusak serta menghancurkan barangbarang milik sesama. Bullying jenis ini adalah yang paling tampak dan mudah untuk diidentifikasi, karena langsung bersentuhan dengan fisik antara pelaku dan korban. Bully fisik ini merupakan hal yang tak jarang di temui di kalangan siswa sekolah dasar, kontrol emosi yang belum stabil membuat mereka cenderung lebih nekat untuk melakukan aksi kekerasan fisik.

\section{3) Bullying Relasional (Mental Psikologis)}

Bullying relasional salah satu bentuk bullying yang tidak dapat diukur, dan tidak tampak oleh kasat mata, jenis bullying relasional ini dapat menyebabkan menurunnya mental seorang anak, dan mengakibatkan psikologi korban terganggu dan degradasi moral bagi pelaku.

4) Bullying Elektronik

Bullying Elektronik adalah salah satu bentuk perilaku bullying yang dilakukan pelakunya melalui sarana elektronik seperti komputer, internet, e-mail, dan sebagainya. Biasanya ditujukan untuk meneror korban dengan menggunakan tulisan, animasi, gambar dan rekaman vidio atau film yang sifatnya mengintimidasi, menyakiti atau menyudutkan. Bullying jenis ini jarang di temui di tingkat sekolah dasar, karena pada usia sekolah dasar seorang anak biasanya lebih banyak berinteraksi langsung dibanding dengan media sosial.

3. Peran pendidikan moral untuk mengurangi aksi bully

a) Peran pendidikan moral

Pendidikan di sekolah khususnya sekolah dasar tidak hanya tentang pelajaran yang diberikan oleh guru, akan tetapi pendidikan untuk anak juga mencakup pendidikan moral yang tidak bisa diperoleh dari buku. Pendidikan moral merupakan salah pendidikan yang berhubungan dengan perilaku seseorang, baik itu perkataan ataupun perbuatan, pendidikan moral untuk anak sekolah dasar sangatlah penting, agar anak tersebut paham perbuatan yang benar dan yang salah, jadi ketika anak sekolah dasar ingin melakukan sesuatu, dia sudah paham apakah yang dilakukannya benar atau salah, termasuk tindakan bully, anak yang memahami pendidikan moral tidak akan melakukan aksi bully, karena mereka tau bahwa bully adalah tindakan yang salah dan dapat melukai temannya, baik batin maupun fisik. Jika ada siswa sekolah dasar yang masih melakukan aksi bully, berarti siswa tersebut belum memiliki pemahaman yang mendalam tentang pendidikan moral. 
Agar nilai-nilai moral dapat berperan dengan baik, diperlukan guru, pejuang moral yang tidak pernah gentar, putus asa atau frustasi meskipun rintangan, halangan, lingkungan tidak kondusif, dan harus berhadapan dengan keadaan distruktif. Dengan tidak jemu-jemunya menerapkan pendidikan untuk mewujudkan nilai moral secara universal yang menghargai orang lain termasuk tidak melakukan aksi bullying (Sigit Dwi Kusrahmdi 2007:9)

Jadi, nilai moral dibawa seorang guru yang meyakini kebenaran moral sebagai ideologi ideal dan harus ditanamkan pada setiap hati (personal, individu) khsusnya anak SD agar suatu hari nanti kehidupan bangsa yang menjunjung nilai-nilai moral dapat terwujud. Dengan adanya pendidikan moral yang sudah disemaikan dalam keluarga, diajarkan di sekolah oleh guru dan masyarakat diharapkan setiap anak dapat menerapkan nilai moral dalam totalitas kehidupan bermasyarakat dan berbangsa. Modal nilai moral yang sudah ada dalam diri anak merupakan lahan yang subur bagi anak-anak usia SD untuk hidup bersosial termasuk tidak melakukan aksi bully atau hal lain yang menyebabkan kerugian bagi orang lain.

b) Upaya mengurangi aksi bully di tingkat sekolah dasar

Bullying bisa terjadi dimana saja dan kapan saja, tergantung situasi yang ada, pada umumnya bullying dapat terjadi apabila ada pelaku, korban dan situasi yang mendukung dan tidak menutup kemungkinan sekolah menjadi tempat berlangsungnya aksi bully, karena di sekolah siswa bisa bertemu dengan banyak teman sebayanya. Beberapa hal yang diduga menjadi penyebab bullying datang dari arah pelaku dan korban bullying. Ratarata anak yang menjadi pelaku dan korban bullying sama-sama memiliki karakteristik khusus yang berhubungan dengan kebiasaan emosi, dan cara berpikir masing-masing. Namun yang pasti pelaku dan korban bullying memiliki perbedaan yang menyolok sehingga pelaku merasa tidak bisa berteman dengan si korban dan justru menganggap korban adalah sasaran empuk untuk memuaskan hasrat mengganggunya.

Menurut Afin Murtie (2014:44-46) bullying di sebabkan oleh beberapa hal : (1) kecenderungan pelaku untuk melakukan bullying; (2) kecenderungan korban untuk dibully; (3) situasi yang memungkinkan terjadinya bullying.

Guru yang berperan sebagai pendidik tidak hanya bertanggung jawab pada nilai akademis siswa, tetapi juga memiliki tanggung jawab dalam membentuk tingkah laku dan karakter siswa. Dalam kasus bullying yang terjadi pada siswa, guru berhak dengan segera melakukan berbagai tindakan untuk merespon perilaku bullying siswa agar terhindar dari berbagai macam kekerasan. Sesuai dengan amanah Undang-Undang Republik Indonesia Nomor 23 Tahun 2002 tentang Perlindungan Anak, pasal 4 yang berbunyi "Setiap anak berhak untuk dapat hidup, tumbuh, berkembang, dan berpartisipasi secara wajar sesuai dengan harkat dan martabat kemanusiaan, serta mendapat perlindungan dari kekerasan dan diskriminasi".

Menurut Yuyarti (2018:172) upaya yang dapat dilakukan untuk mengatasi dan menanggulangi tindak kekerasan seperti bullying melalui penanaman pendidikan moral: (1) memperkuat pengendalian sosial, hal ini dapat dimaknai sebagai berbagai cara yang digunakan pendidik untuk menertibkan peserta didik yang melakukan penyimpangan, termasuk tindak kekerasan dengan melakukan pengawasan dan penindakan; (2) mengembangkan budaya meminta dan memberi maaf; (3) menerapkan prinsip-prinsip anti kekerasan; (4) memberikan pendidikan perdamaian kepada generasi muda; (5) meningkatkan dialog dan komunikasi intensif antar siswa dalam sekolah; (6) menyediakan katarsis (penyucian diri); (7) melakukan usaha pencegahan tindak kekerasan (bullying) di sekolah.

Sebagai evaluator guru memeng harus lebih kreatif dan inofatif dalam menyikapi berbagai persoalan janggal yang akan 
Fianolita Purnaningtias, dkk.

terjadi pada masa sekolah dasar, guru harus mampu menjadi pendidik yang tidak hanya sekadar transfer ilmu, melainkan guru harus memperhatikan dan mengamati setiap perkembangan peserta didik, utamanya dalam perkembangan moral peserta didik, beberapa hal yang bisa dilakukan oleh guru untuk mengembangkan moral peserta didiknya adalah dengan menjadi seorang guru sekaligus orang tua yang memberikan perhatian dan kasih sayang kepada peserta didik, terlepas dari itu seorang guru perlu melakukan pendekatan baik secara personal maupun kelompok untuk membangun komunikasi dan hubungan yang baik antara pendidik dengan peserta didik. Hal ini dianggap cukup efektif untuk mengontrol perkembangan peserta didik.

\section{Kesimpulan}

Moral merupakan sebuah jati diri dan karakter suatu bangsa, setiap anggota negara harus menjunjung nilai moral agar tercipta bangsa yang luhur, berbudi pekerti, dan menghargai perbedaan. Dengan nilai moralitas yang tinggi maka berbagai penyimpangan seperti aksi bullying dapat dikurangi secara perlahan.

Bullying merupakan suatu bentuk kekerasan yang dilakukan oleh seseorang terhadap teman sebaya atau kepada seseorang yang di anggap lebih lemah dan rendah untuk mendapatkan keuntungan atau kepuasan tertentu.

Bullying memiliki dampak yang cukup berbahaya bagi pelaku dan korban, perlu adanya perhatian khusus tersadap persoalan ini baik dari orang tua, guru dan lingkungan melalui pendekatan khusus dan bimbingan yang intensif serta komprehensif.

\section{DAFTAR PUSTAKA}

Afin Murtie. 2016 “Pendidikan Karakter Berbasis Keluarga”. Yogyakarta: Ar-Ruzz Media

Amirullah Syarbini. Afin Murtie. 2014 "Cegah dan Stop Bullying pada Anak Berkebutuhan Khusus”. Yogyakarta: Maxima.

Eli Wardiati. 2017. "Pengaruh Bullying Terhadap Moralitas Siswa pada SMP Darul Hikmah Kabupaten Aceh jaya”. Skripsi. Fakultas Tarbiyah dan Keguruan, Prodi Pendidikan Agama Islam: Aceh

Fatimah Ibda. 2012." Pendidikan Moral Anak Melalui Pengajaran Bidang Studi PPKn dan Pendidikan Agama". Jurnal IImiah Didaktika Februari 2012

Ilham Hudi 2017. "Pengaruh Pengetahuan Moral Terhadap Perilaku Moral pada Siswa SMP Negeri Kota Pekan Baru Berdasarkan Pendidikan Orang Tua”. Jurnal Moral Kemasyarakatan - VOL.2, NO.1, JUNI 2017

Sigit Dwi Kusrahmadi. 2007 "Pentingnya Pendidikan Moral Bagi Anak Sekolah Dasar". jurnal: Dinamika Pendidikan No. 1/ Th. XIV / Me; 2007

Sisca Indriyani. 2019 "Analisis Perilaku Bullying Siswa Seklah Menengah Atas Al-azhar 3 Bandar Lampung Tahun 2018/2019" Skripsi. FKIP, Program Studi Bimbingan dan Konseling, Universitas Lampung : Lampung 
ISSN 2548-9119

Yuyarti. 2018. "Mengatasi Bullying Melalui Pendidikan Karakter”. Universitas Negeri Semarang. : Jurnal Kreatif Semarang 